RESEARCH ARTICLE

\title{
BIOREMEDIATION USING Bacillus subtilis AND Saccharomyces cerevisiae TO REDUCE CHROMIUM IN ELECTROPLATING LIQUID WASTE
}

\author{
Mardiyono $^{1 *}$, Sajidan $^{2}$, Mohammad Masykuri $^{3}$, and Prabang Setyono ${ }^{4}$ \\ ${ }^{1}$ Department of Environmental Science, Post Graduate Programme, Universitas Sebelas Maret (UNS), \\ JI. Ir. Sutami No.36 A, Pucangsawit, Jebres, Surakarta, Jawa Tengah 57126, Indonesia \\ ${ }^{2}$ Department of Biology Education, Faculty of Teacher Training and Education, UNS \\ ${ }^{3}$ Department of Chemical Education, Faculty of Teacher Training and Education, UNS \\ ${ }^{4}$ Department of Environmental Science, Faculty of Mathematics and Science, UNS
} Submitted: 2019-05-02 Accepted: 2019-12-16

\begin{abstract}
The electroplating industry produces liquid waste containing a small number of heavy metals but is toxic. Wastewater containing chromium ( $\mathrm{Cr}$ ) absorbed into the soil will affect soil fertility. Waste management is needed so that the abiotic and biotic environment is not poisoned by $\mathrm{Cr}$. Bioremediation using bacterial and fungal microbes are applicable to reduce $\mathrm{Cr}$ levels in electroplating liquid waste. The purpose of this research was to investigate the reduction level of $\mathrm{Cr}$ in electroplating liquid waste through bioremediation using Bacillus subtilis and Saccharomyces cerevisiae. Laboratory experiments were conducted using variations in microbial concentrations $\left(10^{2.5}\right.$ cells ml ${ }^{-1}$ and $10^{5}$ cells $\mathrm{ml}^{-1}$ ), variations in microbial types (Bacillus subtilis bacteria, Saccharomyces cerevisiae fungi, and mixtures of both microbes), and variations in incubation time $(6,12$, and 24 hours). The initial $\mathrm{Cr}$ concentration and the results of the bioremediation process were determined by measuring the absorbance and the $\mathrm{Cr}$ levels using Atomic Absorption Spectrophotometry (AAS). Based on experiments, the use of Bacillus subtilis $10^{2.5} \mathrm{cells} \mathrm{ml}^{-1}$ with a 24-hour incubation time reach the highest percentage reduction in $\mathrm{Cr}(88.96 \%)$, followed by 12 -hours incubation time $(84.73 \%)$, and 6-hours incubation time (79.21\%). Furthermore, the use of a microbial mixture of Bacillus subtilis and Saccharomyces cerevisiae $10^{2.5}$ cells ml ${ }^{-1}$ with 6 -hours, 12 -hours and 24 -hours incubation time was able to reduce the levels of $\mathrm{Cr}$ respectively by $77.46 \% ; 80.18 \%$ and $83.04 \%$. Next, Saccharomyces cerevisiae $10^{5} \mathrm{cells} \mathrm{ml}^{-1}$ with 6-hours, 12 -hours, and 24-hours incubation time was able to reduce levels of $\mathrm{Cr}$ in a row by $50.17 \% ; 52.35 \%$ and $55.63 \%$. The results of this study indicate that the bioremediation process using the microbial Bacillus subtilis and Saccharomyces cerevisiae is proven to reduce the levels of $\mathrm{Cr}$ in the electroplating industry wastewater. The highest reduction results were achieved on the use of 24-hour incubation time and the use of Bacillus subtilis with a concentration of $10^{2.5}$ cells ml $l^{-1}$ at $88.96 \%$.
\end{abstract}

Keywords: Bioremediation, Bacillus subtilis, Chromium heavy metal, Electroplating liquid waste, Saccharomyces cerevisiae

How to Cite: Mardiyono, Sajidan, Masykuri, M., and Setyono, P. (2019). Bioremediation Using Bacillus subtilis and Saccharomyces cerevisiae to Reduce Chromium in Electroplating Liquid Waste. Sains Tanah Journal of Soil Science and Agroclimatology, 16(2): 191-202 (doi: 10.20961/stjssa.v16i2.29730)

Permalink/DOI: http://dx.doi.org/10.20961/stjssa.v16i2.29730

* Corresponding Author:

Email:mardiyono.md@gmail.com

\section{INTRODUCTION}

The electroplating industry is one of the 
industries that produce liquid waste containing hazardous and toxic materials (Nurhasni, Salimin, \& Nurfitriyani, 2013). Electroplating is an electrochemical way to coat the metal using a metal deposition principle. Metals commonly used for coatings are chromium, cadmium, copper, gold, nickel, silver, and other metals. The electroplating industry is one of the industrial activities that can produce hazardous and toxic liquid waste (Nurhasni et al., 2013). Electroplating industry (metal coating) is a type of industry that has the potential to produce waste, especially liquid waste, which can pollute the environment (Qin, Chai, Ju, \& Hamamoto, 2018).

In the Periodic Table, Chrome $(\mathrm{Cr})$ is a transition element in group VI-B, period 4. Due to the nature of the transition, $\mathrm{Cr}$ is included in the metal element. Chrome metal has an atomic number of 24 and has an atomic mass of 51.996; a density of $7.19 \mathrm{~g} \mathrm{~mL}^{-1}$; boiling point $2,665^{\circ} \mathrm{C}$, and melting point $1,875^{\circ} \mathrm{C}$. $\mathrm{Cr}$ has various valences, including chrome (III) and chrome (VI) which are important in the ecological system (Focardi, Pepi, \& Focardi, 2013; Sharaf, Gasmeleed, \& Musa, 2013).

$\mathrm{Cr}$ is mostly found in the metal coating industry wastewater or paint industry in the form of dichromate anion $\left(\mathrm{Cr}_{2} \mathrm{O}_{7}^{2-}\right)$. $\mathrm{Cr}$ is the seventh element with an abundant presence on earth (Mohanty \& Patra, 2013). The use of $\mathrm{Cr}$ is in alloys, for example, iron metal alloys, steel coatings, paint, and pigment products, leather tanning, wood preservation, chemical production and pulp, and paper products. This industry plays a major role in the contamination of chrome metal with adverse effects on biological and ecological species (Ghani, 2011).

The presence of chrome $(\mathrm{Cr})$ heavy metals in waters must be controlled because their negative impacts can pollute the environment and torment the health of humans, and other living things. The hazardous levels of $\mathrm{Cr}$ oxidation are +3 and +6 , which being toxic to animals, humans, and plants (Focardi et al., 2013; Mohanty \& Patra, 2013; Wolińska, Stępniewska, \& Włosek, 2013). Cr(VI) ions can easily be absorbed by the human body and subsequently accumulate in the food chain then cause severe health problems including skin irritation, respiratory damage, intestinal corrosion, ulcers, even lung cancer (Qin et al., 2018), gene mutations, carcinogenic (Das et al., 2015; Hanifa, 2018), and teratogenic (Focardi, Pepi, \& Focardi, 2013). The mutagenic nature of $\mathrm{Cr}(\mathrm{VI})$ ions is categorized as the number one carcinogen in humans according to the International Agency for Research on Cancer (Jaishankar, Tseten, Anbalagan, Mathew, \& Beeregowda, 2014).

According to the Government Regulation of the Republic of Indonesia Number 101 Year 2014 (PP 101/2014) on the Management of Hazardous and Toxic Substances, any person who produces hazardous and toxic waste is obliged to manage the waste of hazardous and toxic substances produced (Peraturan Menteri, 2014a). The electroplating industry is obliged to manage waste before being discharged into the environment so that the heavy metal content does not exceed the maximum rate allowed by the government. The maximum rate of $\mathrm{Cr}$ in waste that is allowed is $0.5 \mathrm{mg} \mathrm{l}^{-1}$ (Peraturan Menteri, 2014b). Action is needed to reduce or even eliminate the $\mathrm{Cr}$ content, both in the form of total chrome and in the form of $\mathrm{Cr}(\mathrm{VI})$ ions by carrying out waste treatment before being discharged into free waters.

Wastewater treatment containing heavy metals has been carried out including precipitation ( $\mathrm{Mu}$, Wang, Bu, Liu, \& Zhao, 2018), electrocoagulation (Sadyrbaeva, 2016; Makde \& Hedaoo, 2018), electrodialysis, (Golbaz, Jonidi, Rafiee, \& Rezaei, 2014; Hegazi, 2013), adsorption (Khan, Islam, Farooqi, Ayub, \& Basheer, 2019; Permana, Haryati, \& Bustan, 
2017), and bioremediation. Bioremediation can be used to overcome environmental problems by utilizing microorganisms that aim to reduce levels of pollutants (Priadie, 2012). The bioremediation process is relatively economical, proven to be effective in reducing the adverse effects of pollution and making contaminated soils less polluted and free of toxic compounds (Verma \& Kuila, 2019). Pseudomonas aeruginosa has been used to reduce nickel and chromium levels in metal coating industry wastewater (Mardiyono \& Samsumaharto, 2016). The concentration of Pseudomonas aeruginosa and Bacillus subtilis $10^{5}$ cells mll ${ }^{-1}$ and $10^{2.5}$ cells ml ${ }^{-1}$ with a variation of incubation time of 6 hours, 12 hours, and 24 hours was proven to reduce $\mathrm{Cr}(\mathrm{VI})$ levels (Kurniawan, 2014). The Concentration of $10^{2.5}$ cells $\mathrm{ml}^{-1}$ decreased $\mathrm{Cr}(\mathrm{VI})$ levels higher than the concentration of $10^{5}$ cells $\mathrm{ml}^{-1}$, while the 24 hour incubation time decreased the highest levels of $\mathrm{Cr}(\mathrm{VI})$.

Waste management is needed to reduce the level of $\mathrm{Cr}$ in waste before being discharged into the environment to overcome the negative impacts and dangers of $\mathrm{Cr}$ waste in the electroplating industry. The electroplating industry wastewater treatment is done using variations in microbial administration (Bacillus subtilis bacteria, Saccharomyces cerevisiae fungus, and a mixture of both), variations in microbial concentrations $\left(10^{2.5}\right.$ cells $\mathrm{ml}^{-1}$ and $10^{5}$ cells $\mathrm{ml}^{-1}$ ), and variations in microbial incubation time (6 hours, 12 hours, and 24 hours). Before and after the bioremediation process, $\mathrm{Cr}$ was determined by the Atomic Absorption Spectrophotometry method. The purpose of this study is to reduce the levels of $\mathrm{Cr}$ in electroplating industrial wastewater through bioremediation using Bacillus subtilis and Saccharomyces cerevisiae, and variations in concentration and incubation time.

\section{MATERIAL AND METHODS}

This research was conducted in October 2018 to March 2019 in the central laboratory of Universitas Sebelas Maret and Microbiology Laboratory and Water Chemistry Laboratory of Setia Budi University, Surakarta. Tools used in this research include $\mathrm{pH}$ sticks, bottles, flasks, volume pipette, suction cup, centrifuge, filter paper, test tube, drop pipette, AAS. While the material used in this research was electroplating liquid waste, Bacillus subtilis bacteria, Saccharomyces cerevisiae fungi, $\mathrm{H}_{2} \mathrm{SO}_{4} 0.2 \mathrm{~N}, \mathrm{~K}_{2} \mathrm{Cr}_{2} \mathrm{O}_{7}$ p.a., concentrated $\mathrm{HNO}_{3}$, aquadest, aquabidestilata, label paper, and Whatman filter paper.

The procedure of this research was carried out using the bioremediation method through the following stages:

\section{Microbial preparation procedures}

The bacteria used are bacterial Bacillus subtilis, and the fungi Saccharomyces cerevisiae. Isolates of Bacillus subtilis are reproduced in a liquid medium LB (Luria Bertany) with a composition of isolates of 100 $\mathrm{mL}$ namely $1 \mathrm{G}$ Tryptophan, $0.5 \mathrm{~g}$ Yeast extract, and $0.5 \mathrm{~g} \mathrm{NaCl}$. Furthermore, the isolates of Saccharomyces cerevisiae are reproduced in Sabouraud Glucose Agar (SGA) liquid media with a composition of isolates $100 \mathrm{ml}$ of Mycological peptone 10 grams, Glucose 40 grams, and Agar 15 grams.

\section{Carrier media preparation}

The carrier media used in this study is rice bran. Rice bran weighs 30 grams and put in a petri dish. Petri dishes containing rice bran wrapped in paper and put in heat-resistant plastic. Then put in an autoclave to be sterilized with a temperature of $121^{\circ} \mathrm{C}$ at a pressure of 1 atm, for 15 minutes.

\section{Planting bacteria into the media carrier}

Planting bacteria into the carrier media is done by mixing $10 \mathrm{ml}$ of bacteria, $15 \mathrm{ml}$ aquadest, and 30 grams of rice bran for the colony's bacterial level $10^{2.5}$ cells $\mathrm{ml}^{-1}$. While the 
colony bacteria level $10^{5}$ cells $\mathrm{ml}^{-1}$ is performed by mixing $10 \mathrm{ml}$ of bacteria, $5 \mathrm{ml}$ of aquadest, and $30 \mathrm{~g}$ of rice bran. The resulting mixture was then dried in the sun for one day in bright air conditions (Kurniawan, 2014).

\section{Sampling}

Samples were taken from the inlet at the Bina Chroom electroplating industry in Mojosongo, Surakarta, Central Java. Sampling was carried out three times a day such as in the morning, afternoon and evening, as much as 15 liters each. Initial characteristics of the wastewater were $35^{\circ} \mathrm{C}$, smelling of sewage, $\mathrm{pH}$ 8.0 and yellowish color.

Preparation of a suspension of Bacillus subtilis, Saccharomyces cerevisiae, and the mixture of both microbes

The microbes were cultured on a suitable medium, taken 2-3 ose included in $100 \mathrm{ml}$ of medium, then incubated at a temperature of $37^{\circ} \mathrm{C}$ for 6 hours, 12 hours, and 24 hours.

Variation types of microbe suspension given to electroplating waste samples

Samples treated with the addition of various types of microbe suspension with a concentration of $10^{2.5}$ cells ml$^{-1}$ and $10^{5}$ cells ml ${ }^{-1}$, then incubated for 6 hours, 12 hours, and 24 hours with pH 7.4 and temperature of $37^{\circ} \mathrm{C}$.

Samples were tested before and after processing with various types of microbes

Before and after incubation, the sample was taken $100 \mathrm{ml}$, added with $5 \mathrm{ml}$ of concentrated $\mathrm{HNO}_{3}$ and heated in electric heating until the test sample solution was almost dry, then added $50 \mathrm{ml}$ of aquabidestilata, put into a $100 \mathrm{ml}$ measuring flask through Whatman filter paper and matched with $100 \mathrm{ml}$ solution $\mathrm{H}_{2} \mathrm{SO}_{4} 0.2 \mathrm{~N}$. The test solution is transferred into the cuvette then the absorbance was read using an (AAS) (SNI 06-6989.17-2004).

The research was conducted using Pretest Posttest Design, by determining the levels of $\mathrm{Cr}$ before and after the additional treatment of Bacillus subtilis and Saccharomyces cerevisiae. The independent variables (factors) in this research include variations in microbial administration, variations in microbial concentrations, and variations in microbial incubation time. The data that has been collected is further analyzed using the three-way Analysis of variance (ANOVA) to determine the difference in $\mathrm{Cr}$ concentrations reviewed from these three factors.

\section{RESULTS}

The concentration of $\mathrm{Cr}$ after bioremediation with variations in microbial administration, concentrations, and incubation time

Concentration of $\mathrm{Cr}$ after bioremediation with Bacillus subtilis (Bs), Saccharomyces cerevisiae $(\mathrm{Sc})$ and mixtures of both microbes $(\mathrm{Bs}+\mathrm{Sc})$, variation of microbial concentrations $\left(10^{2.5}\right.$ cells $\mathrm{ml}^{-1}$ and $10^{5}$ cells $\left.\mathrm{ml}^{-1}\right)$, and incubation times 6 hours, 12 hours, and 24 hours are presented in Table 1, Table 2, and Table 3. Figure 1, Figure 2, and Figure 3 give the visualization of $\mathrm{Cr}$ concentration after bioremediation.

Table 1 shows the concentration of $\mathrm{Cr}$ after the addition of various microbial administration, microbial concentration and 6 hours incubation time, which can reduce the $\mathrm{Cr}$ levels from the initial level of $2.5161 \mathrm{ppm}$. Levels of reduction depending on the type of microbe and concentration used. The highest reduction is in the addition of $10^{2.5}$ cells $\mathrm{ml}^{-1}$ Bacillus subtilis and the lowest reduction is in the addition of $10^{5}$ cells $\mathrm{ml}^{-1}$ Saccharomyces cerevisiae.

Table 2 and Table 3 also show that in the incubation time of 12 hours and 24 hours, Bacillus subtilis reduce $\mathrm{Cr}$ levels higher than Saccharomyces cerevisiae. In the variation of $10^{2.5}$ cells $\mathrm{ml}^{-1}$ microbial concentrations can reduce the $\mathrm{Cr}$ levels higher than the concentration of $10^{5}$ cells mll $\mathrm{l}^{-1} \cdot 10^{2.5}$ cells $\mathrm{ml}^{-1}$ 
Bacillus subtilis was seen to reduce the highest levels of $\mathrm{Cr}$ levels, followed by $10^{2.5}$ cells $\mathrm{ml}^{-1}$ mixture of Bacillus subtilis and Saccharomyces cerevisiae. The addition of Saccharomyces cerevisiae $10^{5}$ cells $\mathrm{ml}^{-1}$ reduced the lowest levels of $\mathrm{Cr}$ levels.

\section{Average concentration percentage of $\mathrm{Cr}$ after bioremediation with variations in microbial administration, concentrations, and incubation time}

The average $\mathrm{Cr}$ concentration percentage from the bioremediation process on the use of each microbial administration, concentration, and incubation time are presented in Table 4. The visualization of $\mathrm{Cr}$ concentration after bioremediation can be seen in Figure 3.

\section{Statistical analysis}

Based on the data in Table 5, the research hypothesis was tested using a threeway Analysis of Variance (ANOVA). The purpose of the three-way ANOVA is to determine the difference in $\mathrm{Cr}$ concentration by interaction of three factors, namely microbial administration (Bacillus subtilis, Saccharomyces cerevisiae, and a mixture of both), microbial concentration (10 2.5 cells $\mathrm{ml}^{-1}$ and $10^{5}$ cells $\mathrm{ml}^{-1}$ ), and incubation time ( 6 hours, 12 hours, and 24 hours). The requirements that must be fulfilled in the ANOVA test are the p-value in the interaction of three factors/variables was less than 0.05 . The results of three-way ANOVA are presented in Table 5.

Based on three-way ANOVA, the F value of the interactions between three factors was 4.627 with a significance of $0.004(p<0.05)$. These results indicate that the interaction between variations in microbial administration, microbial concentration, and incubation time significantly influences the reduction in $\mathrm{Cr}$ concentration in electroplating wastewater.
Furthermore, the $\mathrm{F}$ value on the interaction between variations in microbial administration and microbial concentration was 73.990 with a $p=0.0001(p<0.05)$. Likewise, in the interaction between microbial administration and incubation time, the $F$ value of 4.961 was obtained with $p=0.003(p<0.05)$. Both of these results indicate that there are significant interactions between variations in microbial administration and microbial concentrations as well as between microbial administration and incubation time. But in the interaction between microbial concentration and incubation time, the $F$ value was 1.599 with $p=0.216$ ( $p>0.05)$, so there was no significant interaction between microbial concentration and incubation time.

\section{DISCUSSION}

Based on Table 1 and Table 2, $10^{2.5}$ cells $\mathrm{ml}^{-1}$ Bacillus subtilis decreased $\mathrm{Cr}$ concentration greatest than all treatment during 6 hours incubation, with changes in $\mathrm{Cr}$ concentration from initial $2.5161 \mathrm{ppm}$ to $0.5232 \mathrm{ppm}(\mathrm{Cr}$ concentration decrease was $1.9929 \mathrm{ppm}$ ). The lowest decrease is in the addition of $10^{5}$ cells $\mathrm{ml}^{-1}$ Saccharomyces cerevisiae which is equal to $1.2623 \mathrm{ppm}$.

The reduction level of $\mathrm{Cr}$ concentration during 12 hours incubation from initial waste level of $2.5161 \mathrm{ppm}$ from high to low, respectively in the use of $10^{2.5}$ cells $\mathrm{ml}^{-1}$ Bacillus subtilis (2.1320 ppm), $10^{2.5}$ cells $\mathrm{ml}^{-1}$ mixture of Bacillus subtilis and Saccharomyces cerevisiae (2.0174 ppm), $10^{5}$ cells $\mathrm{ml}^{-1}$ mixture of Bacillus subtilis (1,9196 ppm), $10^{5}$ cells $\mathrm{ml}^{-1}$ Bacillus subtilis and Saccharomyces cerevisiae (1.7955 ppm), $10^{2.5}$ cells $\mathrm{ml}^{-1}$ Saccharomyces cerevisiae

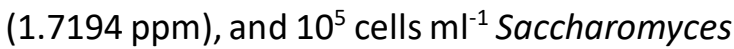
cerevisiae (1.3172 ppm). 


\section{RESEARCH ARTICLE}

Table 1. $\mathrm{Cr}$ concentration after bioremediation with variation in microbial administration, concentration and incubation time (initial $\mathrm{Cr}$ concentration $=2.5161 \mathrm{ppm} \mathrm{mg}^{-1}$ liter $^{-1}$ )

\begin{tabular}{|c|c|c|c|c|}
\hline \multirow[t]{2}{*}{ Treatment } & \multirow{2}{*}{$\begin{array}{l}\text { Microbial concentration } \\
\text { (cells } \mathrm{ml}^{-1} \text { ) }\end{array}$} & \multicolumn{3}{|c|}{ Cr Concentration After Bioremediation } \\
\hline & & 6 hours & 12 hours & 24 hours \\
\hline \multirow{4}{*}{ Bs } & \multirow{4}{*}{$10^{2.5}$} & 0.5194 & 0.3796 & 0.3339 \\
\hline & & 0.5229 & 0.3861 & 0.2053 \\
\hline & & 0.5273 & 0.3867 & 0.2941 \\
\hline & & Average: 0.5232 & Average: 0.3841 & Average: 0.2778 \\
\hline \multirow{4}{*}{ Bs } & \multirow{4}{*}{$10^{5}$} & 0.6782 & 0.5976 & 0.6090 \\
\hline & & 0.6712 & 0.5973 & 0.4968 \\
\hline & & 0.6768 & 0.5943 & 0.5289 \\
\hline & & Average: 0.6754 & Average: 0.5965 & Average: 0.5449 \\
\hline \multirow{4}{*}{ Sc } & \multirow{4}{*}{$10^{2.5}$} & 0.8221 & 0.7935 & 0.6997 \\
\hline & & 0.8212 & 0.7952 & 0.7485 \\
\hline & & 0.8312 & 0.8014 & 0.8114 \\
\hline & & Average: 0.8248 & Average: 0.7967 & Average: 0.7532 \\
\hline \multirow{4}{*}{ Sc } & \multirow{4}{*}{$10^{5}$} & 1.2598 & 1.1962 & 1.1167 \\
\hline & & 1.2481 & 1.1948 & 1.0844 \\
\hline & & 1.2534 & 1.2058 & 1.1485 \\
\hline & & Average: 1.2538 & Average: 1.1989 & Average: 1.1165 \\
\hline \multirow{4}{*}{$B s+S c$} & \multirow{4}{*}{$10^{2.5}$} & 0.5721 & 0.4967 & 0.4227 \\
\hline & & 0.5663 & 0.5021 & 0.4294 \\
\hline & & 0.5629 & 0.4974 & 0.4279 \\
\hline & & Average: 0.5671 & Average: 0.4987 & Average: 0.4267 \\
\hline \multirow{4}{*}{$B s+S c$} & \multirow{4}{*}{$10^{5}$} & 0.7693 & 0.7195 & 0.6721 \\
\hline & & 0.7655 & 0.7188 & 0.6741 \\
\hline & & 0.7712 & 0.7234 & 0.6672 \\
\hline & & Average: 0.7687 & Average: 0.7206 & Average: 0.6711 \\
\hline \multicolumn{2}{|c|}{ Bs : Bacillus subtilis } & \multicolumn{3}{|c|}{ eviciae $\quad$ ppm : part per million $\left(\mathrm{mg} \mathrm{liter}^{-1}\right)$} \\
\hline $\begin{array}{rr}\text { Table 2. Av } \\
\text { ac } \\
\end{array}$ & $\begin{array}{l}\text { ge } \mathrm{Cr} \text { concentration le } \\
\text { histration, concentration a }\end{array}$ & $\begin{array}{r}\text { after bioremed } \\
\text { icubation time (ir }\end{array}$ & $\begin{array}{l}\text { tion with varia } \\
\text { ial } \mathrm{Cr} \text { concentrati }\end{array}$ & $\begin{array}{l}\text { on in microbial } \\
\mathrm{n}=2.5161 \mathrm{ppm})\end{array}$ \\
\hline \multirow[t]{2}{*}{ Treatment } & \multirow{2}{*}{$\begin{array}{l}\text { Microbial concentration } \\
\text { (cells } \mathrm{ml}^{-1} \text { ) }\end{array}$} & \multicolumn{3}{|c|}{ Cr concentration levels of changes (ppm) } \\
\hline & & 6 hours & 12 hours & 24 hours \\
\hline Bs & $10^{2.5}$ & 1.9929 & 2.1320 & 2.2383 \\
\hline Bs & $10^{5}$ & 1.8407 & 1.9196 & 1.9172 \\
\hline Sc & $10^{2.5}$ & 1.6913 & 1.7194 & 1.7629 \\
\hline Sc & $10^{5}$ & 1.2623 & 1.3172 & 1.3996 \\
\hline$B s+S C$ & $10^{2.5}$ & 1.9490 & 2.0174 & 2.0894 \\
\hline$B s+S C$ & $10^{5}$ & 1.7474 & 1.7955 & 1.8450 \\
\hline
\end{tabular}

Table 3. Average $\mathrm{Cr}$ concentration percentage after bioremediation with variation in microbial administration, concentration and incubation time

\begin{tabular}{lcccc}
\hline Treatment & $\begin{array}{c}\text { Microbial concentration } \\
\text { (cells } \mathbf{~ m}^{-1} \text { ) }\end{array}$ & \multicolumn{3}{c}{ Average Cr concentration percentage (\%) } \\
\cline { 2 - 5 } & $10^{2.5}$ & $\mathbf{6}$ hours & 12 hours & 24 hours \\
\hline$B s$ & $10^{5}$ & 79.21 & 84.73 & 88.96 \\
$B s$ & $10^{2.5}$ & 73.16 & 76.28 & 78.34 \\
$S C$ & $10^{5}$ & 67.22 & 68.34 & 70.06 \\
$S C$ & $10^{2.5}$ & 50.17 & 52.35 & 55.63 \\
$B s+S c$ & 77.46 & 80.18 & 83.04 \\
$B s+S c$ & $10^{5}$ & 69.45 & 71.36 & 73.33 \\
\hline
\end{tabular}


Tabel 4. Cr concentration in electroplating liquid waste after bioremediation using a mixture of both microbes $(\mathrm{BS}+\mathrm{SC})$

\begin{tabular}{|c|c|c|c|c|c|c|}
\hline \multirow[b]{2}{*}{$\begin{array}{l}\text { Experiment } \\
\text { number }\end{array}$} & \multirow[b]{2}{*}{ Microbes } & \multirow[b]{2}{*}{$\begin{array}{c}\text { Microbial } \\
\text { concentration }\end{array}$} & \multicolumn{3}{|c|}{$\mathrm{Cr}$ concentration } & \multirow{2}{*}{$\begin{array}{c}\text { Percentage } \\
\text { of decrease } \\
\text { level (\%) }\end{array}$} \\
\hline & & & $\begin{array}{l}\text { Initial } \\
\text { (ppm) }\end{array}$ & $\begin{array}{c}\text { After bioremediation } \\
(\mathrm{ppm})\end{array}$ & $\begin{array}{c}\text { Changes } \\
\text { (ppm) }\end{array}$ & \\
\hline 1 & $\mathrm{BS}+\mathrm{SC}$ & 0 & 2.5909 & 2.5909 & 0 & 0 \\
\hline 2 & $\mathrm{BS}+\mathrm{SC}$ & 0 & 2.4894 & 2.4894 & 0 & 0 \\
\hline 3 & $\mathrm{BS}+\mathrm{SC}$ & 0 & 2.4680 & 2.4680 & 0 & 0 \\
\hline Average & $\mathrm{BS}+\mathrm{SC}$ & 0 & 2.5161 & 2.5161 & 0 & 0 \\
\hline 1 & $\mathrm{BS}+\mathrm{SC}$ & $10^{2.5}$ & 2.5909 & 1.1111 & 1.4798 & 57.12 \\
\hline 2 & $\mathrm{BS}+\mathrm{SC}$ & $10^{2.5}$ & 2.4894 & 1.0844 & 1.405 & 56.44 \\
\hline 3 & $\mathrm{BS}+\mathrm{SC}$ & $10^{2.5}$ & 2.4680 & 1.1485 & 1.3195 & 53.46 \\
\hline Average & $\mathrm{BS}+\mathrm{SC}$ & $10^{2.5}$ & 2.5161 & 1.1165 & 1.3996 & 55.63 \\
\hline 1 & $\mathrm{BS}+\mathrm{SC}$ & $10^{5}$ & 2.5909 & 0.6945 & 1.8964 & 73.19 \\
\hline 2 & $\mathrm{BS}+\mathrm{SC}$ & $10^{5}$ & 2.4894 & 0.7479 & 1.7415 & 69.96 \\
\hline 3 & $\mathrm{BS}+\mathrm{SC}$ & $10^{5}$ & 2.4680 & 0.8120 & 1.656 & 67.10 \\
\hline Average & $\mathrm{BS}+\mathrm{SC}$ & $10^{5}$ & 2.5161 & 0.7532 & 1.7629 & 70.06 \\
\hline
\end{tabular}

Table 5. Analysis of variance

\begin{tabular}{l|r|r|r|r|r}
\hline \multicolumn{1}{c}{ Source } & $\begin{array}{c}\text { Type III Sum of } \\
\text { Squares }\end{array}$ & df & Mean Square & F & Sig. \\
\hline Corrected Model & $3.721^{\mathrm{a}}$ & 17 & .219 & 326.363 & .000 \\
\hline Intercept & 26.454 & 1 & 26.454 & 39441.825 & .000 \\
\hline Microbes (A) & 2.388 & 2 & 1.194 & 1780.358 & .000 \\
\hline Concentration (B) & 1.037 & 1 & 1.037 & 1545.580 & .000 \\
\hline Incubation (C) & .169 & 2 & .085 & 126.170 & .000 \\
\hline A x B interaction & .099 & 2 & .050 & 73.990 & .000 \\
\hline A x C interaction & .013 & 4 & .003 & 4.961 & .003 \\
\hline B x C interaction & .002 & 2 & .001 & 1.599 & .216 \\
\hline A x B x C interaction & .012 & 4 & .003 & 4.627 & .004 \\
\hline Error & .024 & 36 & .001 & & \\
\hline Total & 30.200 & 54 & & & \\
\hline Corrected Total & 3.745 & 53 & & & \\
\hline Remark: R Squar & 5901 & & &
\end{tabular}

Remark: a. R Squared $=.994$ (Adjusted R Squared $=.991$ )

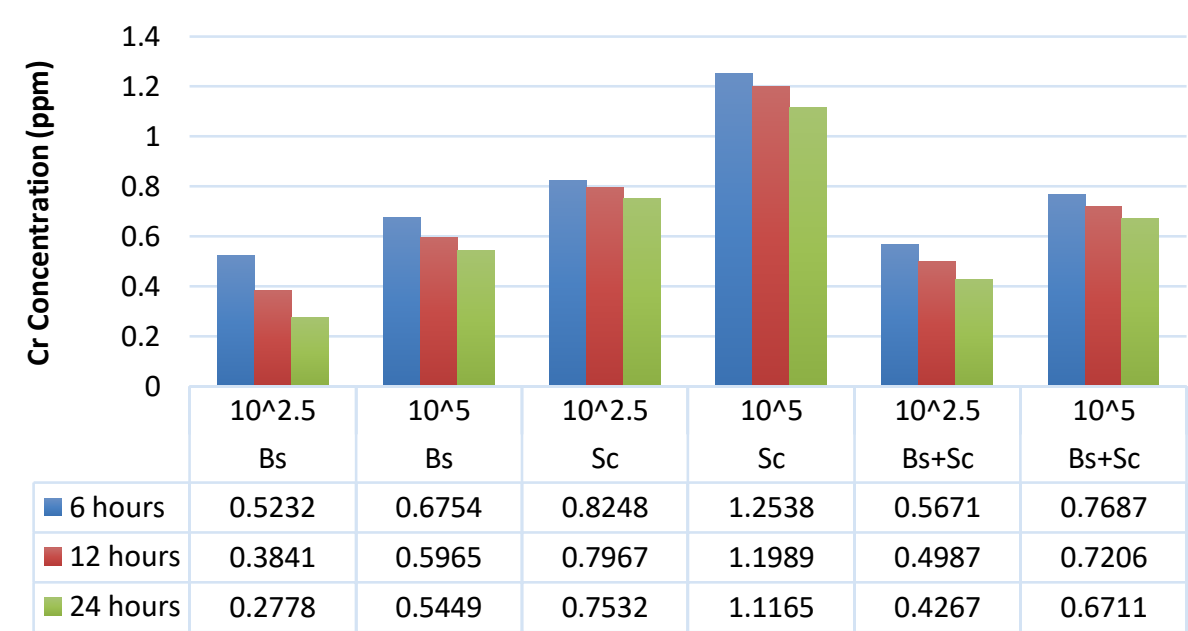

Figure 1. Cr Concentration after bioremediation with variation in microbial administration, concentration and incubation time (initial $\mathrm{Cr}$ concentration $=2.5161 \mathrm{ppm}$ ) 


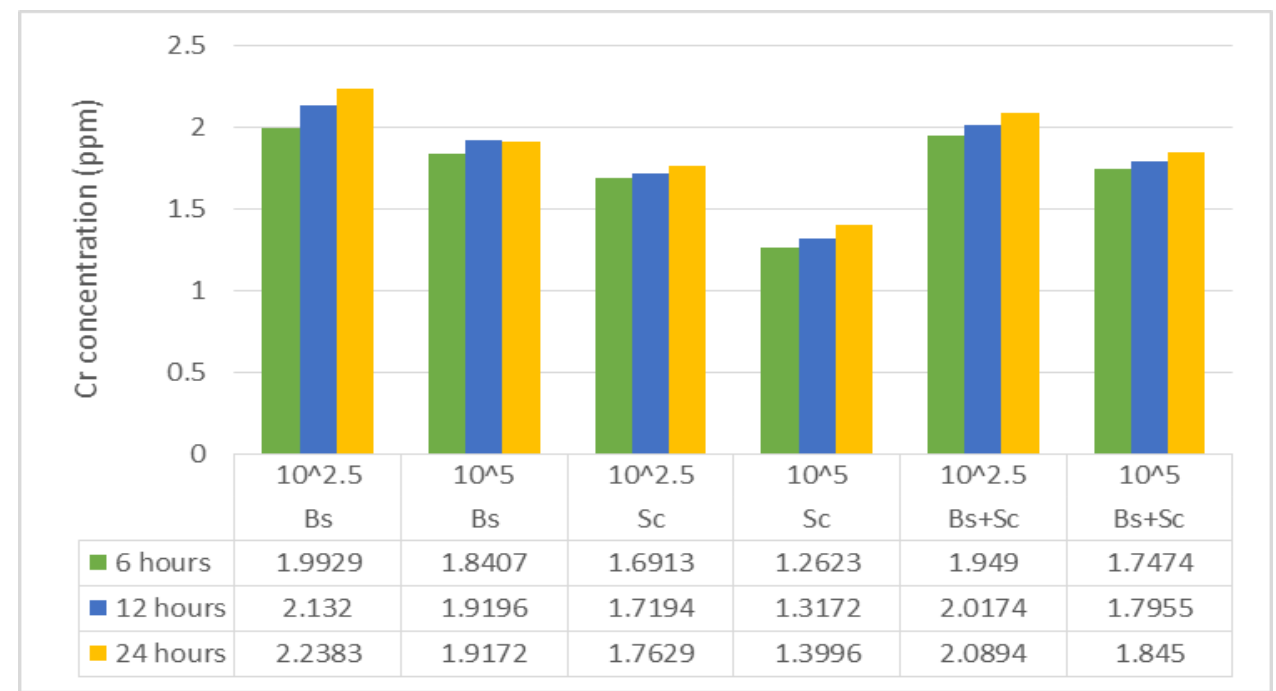

Figure 2. Average concentration of change in $\mathrm{Cr}$ after Bioremediation with Variation in Microbial Administration, Concentration and Incubation Time (Initial Cr Concentration $=2.5161 \mathrm{ppm}$ )

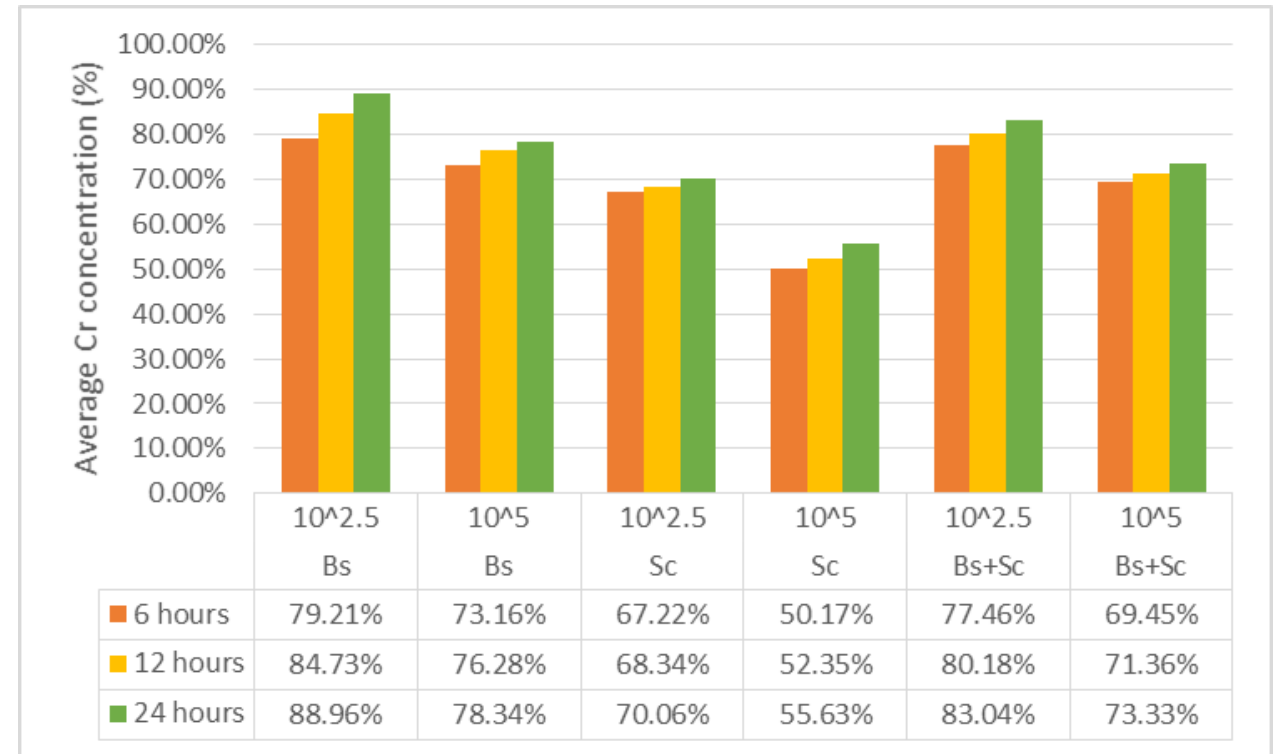

Figure 3. Average $\mathrm{Cr}$ Concentration Percentage after Bioremediation with Variation in Microbial Administration, Concentration and Incubation Time (Initial Cr Concentration $=2.5161 \mathrm{ppm}$ )

The data from Table 1 dan Table 2 showed that the decrease in $\mathrm{Cr}$ concentration after bioremediation is influenced by the length of incubation time. The use of 6 hours incubation time has not shown a large number of $\mathrm{Cr}$ reductions, but the longer incubation time shows an increase in the reduction of $\mathrm{Cr}$ concentration (12 hours and 24 hours incubation time). Incubation time is related to the growth of microbes in the media, microbial growth factors are influenced by the time of interaction with the substrate on the microbial growth media. Microbial growth can be divided into 4 stages, including lag phase, log phase, stationary phase, and death phase (Tamam, 2016). At the 6-hour incubation stage, microbial growth in the lag period has a microorganism activity phase and prepares for the cleavage process, followed by 12-hour incubation, the activity of microorganisms increases and cell division occurs so that there is an increase in the number of cells in the 
microorganism population. This phase occurs from the lag phase to the log phase and exponential growth occurs until finally at 24hour incubation, experiencing a peak of microbial growth phase towards the next 24 hours the stationary phase is reached. So that at 24-hour incubation data obtained the highest reduction in chromium content in all microbial variations used. The microbial growth phase after 24 hours then experiences a death phase and it is possible that microbial activity will decrease (Tamam, 2016).

At the use of microbial concentrations of $10^{2.5}$ cells $\mathrm{ml}^{-1}$ showed a higher decrease compared to concentrations of $10^{5}$ cells $\mathrm{ml}^{-1}$. The concentration of $10^{2.5}$ cells $\mathrm{ml}^{-1}$ microbes contains higher water, causing higher humidity. Bacterial and fungal growth is influenced by humidity and osmotic pressure (Tamam, 2016). The large concentration of bacteria will contain a large bacterial period, causing a greater ability to absorb $\mathrm{Cr}$ in the waste (Wazeck, 2013).

In this study, the concentration of Bacillus subtilis $10^{2.5}$ cells $\mathrm{ml}^{-1}$ showed higher results, made from $10 \mathrm{ml}$ of bacteria plus $15 \mathrm{ml}$ of aquadest, microbes with a concentration of $10^{5}$ cells $\mathrm{ml}^{-1}$ were made of $10 \mathrm{ml}$ of bacteria plus $5 \mathrm{ml}$ of aquadest, each using a rice bran carrier medium as much as $30 \mathrm{~g}$ (Kurniawan, 2014). Conditions of the addition of different aquadest in the volume of microbes and media carriers at the same magnitude will affect the moisture in the media grow microbes.

Another factor of microbial growth is influenced by the pressure of osmosis associated with the availability of water in the media. Water availability in microbial concentrations of $10^{5}$ cells $\mathrm{ml}^{-1}$ less, causing high concentrations in the media to grow microbes and the high concentration of the environment so as to exceed the concentration in cells and resulting in the occurrence of plasmolysis is the discharge of fluids in the cytoplasm of microbial cells. The occurrence of plasmolysis in this cytoplasm causes serious threats due to dehydration in the microbial cells so that the growth of microbes becomes obstructed (the number of microbes becomes fewer) at concentrations of $10^{5}$ cells $\mathrm{ml}^{-1}$ (Tamam, 2016).

The use of bacterial and fungal microbes at the same concentration shows that bacteria can reduce $\mathrm{Cr}$ levels higher. The mechanism of reduction is closely related to the ability of bacteria and fungi to survive in high metal concentrations (Akhmad, Yusran, Mariana, \& Badruzsaufari, 2011). Bacteria in the process of detoxification can be by forming extra polymers that can bind metal as chelates, precipitate metals or transform metals into non-toxic forms (Gayathramma, Pavani, Singh, \& Deepti, 2013).

Microorganisms use cells or metabolites in the form of enzymes to restore the polluted environment by means of absorption which can occur through a process of complexation, chelation, coordination, precipitation, ion exchange or oxidative-reductive processes (Ahemad, 2012; Juwarkar, Misra, \& Sharma, 2014). The bioremediation process for the retrieval of chrome metal ions by Bacillus subtilis from a solution can be done in three ways i.e. (1) Metal adsorbed on the cell surface of microorganisms; (2) The absorption of metal ions enters into cell microorganisms and (3) the chemical transformation of metal ions by microorganisms (Pramono, Rosariastuti, Ngadiman, \& Irfan, 2013).

Table 3 showed that the percentage reduction in $\mathrm{Cr}$ with $10^{2.5}$ cells $\mathrm{ml}^{-1}$ Bacillus subtilis and an incubation time of 6 hours, 12 hours, and 24 hours respectively from high to low were $79.21 \%, 84.73 \%$, and $88.96 \%$. Table 3 also showed that the percentage reduction in $\mathrm{Cr}$ with $10^{2.5}$ cells $\mathrm{ml}^{-1}$ mixture Bacillus subtilis and Saccharomyces cerevisiae with incubation times of 6,12 , and 24 hours, respectively 
$77.46 \%, 80.18 \%$, and $83.04 \%$. Table 4, showed that the lowest decrease of $\mathrm{Cr}$ is in the use of $10^{5}$ cells $\mathrm{ml}^{-1}$ Saccharomyces cerevisiae with the incubation time of 6,12 , and 24 hours, respectively $50.17 \%, 52.35 \%$, and $55.63 \%$.

This research suggests that Bacillus subtilis manages to lower the chrome metal levels greater than that of Saccharomyces cerevisiae. A Bacillus subtilis ability in binding to chrome metal with extracellular fluid and the presence of Cytochrome as a manufacturer of chromate reductase enzymes can alter $\mathrm{Cr}(\mathrm{VI})$, then enter into the inner cell membrane and be converted into $\mathrm{Cr}$ (III) (Das et al., 2015). Saccharomyces cerevisiae has different abilities due to the structure of the cell wall consisting of a drum and mannan, so hen no incoming chrome ions will be placed in the Vacuola and partially secreted from the cell (Ribeiro et al., 2019). The presence of a portion of Chrome ions released again from the cell causes the absorption of chrome metal to be not maximal.

The use of mixed microbes can occur mutually affect (Waluyo, 2019), as seen in the mixture of Bacillus subtilis and Saccharomyces cerevisiae. The influence of one microbe with other microbes can be deadly or reduce life activities (antagonism, competition), microbes with one another there are also mutually reinforcing/beneficial activities of life (mutualism, synergism) and there is no influence (neutralism).

\section{CONCLUSION}

This research established that bioremediation using the microbial Bacillus subtilis and Saccharomyces cerevisiae has been proven to reduce levels of $\mathrm{Cr}$ in the electroplating industry wastewater, and the highest reduction results were achieved on the use of 24-hour incubation time and the use of Bacillus subtilis with a concentration of $10^{2.5}$ cells $\mathrm{ml}^{-1}$ which was $88.96 \%$. Furthermore, the concentration of $10^{2.5}$ cells ml $l^{-1}$ Bacillus subtilis lowers the chrome metal levels most commonly compared to other microbial concentration variations.

\section{REFERENCES}

Ahemad, M. (2012). Implications of Bacterial Resistance Against Heavy Metals in Bioremediation: A Review. IIOABJ, 3(3), 39-46.

Akhmad, F., Yusran, F. H., Mariana, Z. T., \& Badruzsaufari. (2011). Inokulasi bakteri pereduksi kromium heksavalen sebagai upaya bioremediasi lahan pasca tambang. EnviroScienteae, 7, 12-20. https://doi.org/10.20527/es.v7i1.368

Das, M., Nigam, H., Chauhan, S., Pandey, P., Swati, P., Yadav, M., \& Tiwari, A. (2015). Microbial chromium degradation: Biological evolution, mitigation and mechanism. Advances in Applied Science Research, 6(5), 6-12.

Focardi, S., Pepi, M., \& Focardi, S. E. (2013). Microbial Reduction of Hexavalent Chromium as a Mechanism of Detoxification and Possible Bioremediation Applications. In R. Chamy \& F. Rosekranz (Eds.), Biodegradation Life of Science (pp. 321-348). Rijeka, Croatia: InTech. https://doi.org/10.5772/56365

Gayathramma, K., Pavani, K. V, Singh, A. R., \& Deepti, S. (2013). Role of Bacillus Subtilis in Bioremediation of Heavy Metals. IJBR, 6(1), 6-11.

Ghani, A. (2011). Effect of chromium toxicity on growth, chlorophyll and some mineral nutrients of brassica juncea L. Egyptian Academic Journal of Biological Sciences, H. Botany, 2(1), 9-15. https://doi.org/10.21608/eajbsh.2011.17 007

Golbaz, S., Jafari, A. J., Rafiee, M., \& Kalantary, R. R. (2014). Separate and simultaneous removal of phenol, chromium, and cyanide from aqueous solution by coagulation/precipitation: Mechanisms and theory. Chemical Engineering Journal, 253, 251-257. https://doi.org/10.1016/j.cej.2014.05.07 4 
Hanifa, A. R. D. (2018). Pengolahan limbah elektroplanting Untuk Penurunan TSS, Total Krom, Dan Nikel Dengan teknik Fitoremediasi Sistem SSF-Wetland. Institut Teknologi Nasional Malang.

Hegazi, H. A. (2013). Removal of Heavy Metals from Wastewater Using Agricultural and Industrial Wastes as Adsorbents. HBRC Journal, 9(3), 276-282.

Jaishankar, M., Tseten, T., Anbalagan, N., Mathew, B. B., \& Beeregowda, K. N. (2014). Toxicity, mechanism and health effects of some heavy metals. Interdisciplinary Toxicology, 7(2), 60-72. https://doi.org/10.2478/intox-2014-0009 Juwarkar, A. A., Misra, R. R., \& Sharma, J. K. (2014). Geomicrobiology and Biogeochemistry. (N. Parmar \& A. Singh, Eds.) (Vol. 39). Berlin, Heidelberg: Springer Berlin Heidelberg. https://doi.org/10.1007/978-3-64241837-2

Khan, S. U., Islam, D. T., Farooqi, I. H., Ayub, S., \& Basheer, F. (2019). Hexavalent chromium removal in an electrocoagulation column reactor: Process optimization using CCD, adsorption kinetics and $\mathrm{pH}$ modulated sludge formation. Process Safety and Environmental Protection, 122(December 2018), 118-130. https://doi.org/10.1016/j.psep.2018.11.024

Kurniawan, A. (2014). Upaya Penurunan Pencemaran Logam Berat Pb-II Dan Cr-VI Pada Air Lindi (Leachate) Melalui Proses Bioremediasi Dengan Penambahan Pseudomonas aeruginosa dan Bacillus subtilis. Universitas Sebelas Maret.

Makde, K. N., \& Hedaoo, M. N. (2018). Application of Electrocoagulation in Wastewater Treatment: A General Review. International Research Journal of Engineering and Technology (IRJET), 5(12), 1567-1572.

Mardiyono, \& Samsumaharto, R. A. (2016). Pemanfaatan Pseudomonas flourescens untuk Meminimalisir Logam Berat $\mathrm{Cr}$ pada Limbah Cair Industri Elektroplating. Biomedika, 9(1), 60-67. https://doi.org/10.31001/biomedika.v9i 1.263
Mohanty, M., \& Patra, H. K. (2013). Effect of Ionic and Chelate Assisted Hexavalent Chromium on Mung Bean Seedlings (Vigna radiata L. wilczek. var k-851) During Seedling Growth. Journal of Stress Physiology \& Biochemistry, 9(2), 232-241.

Mu, R., Wang, M., Bu, Q., Liu, D., \& Zhao, Y. (2018). Improving lead adsorption through chemical modification of wheat straw by lactic acid. IOP Conference Series: Earth and Environmental Science, 108, 022063. https://doi.org/10.1088/17551315/108/2/022063

Nurhasni, N., Salimin, Z., \& Nurfitriyani, I. (2013). Pengolahan Limbah Industri Elektroplating Dengan Proses Koagulasi Flokulasi. Jurnal Kimia VALENSI, 3(1), 4148. https://doi.org/10.15408/jkv.v3i1.328.

Peraturan Menteri. (2014a). Permen LH no 15 th 2014 ttg Baku Mutu Air Limbah, (1815). Peraturan Menteri. (2014b). PP Nomor 101 Tahun 2014 tentang Pengelolaan Limbah B3, 561-565.

Permana, E., Haryati, S., \& Bustan, M. D. (2017). Studi Pengaruh Waktu Kontak, Laju Alir, dan Ukuran Packing terhadap Adsorpsi $\mathrm{Cr}(\mathrm{VI})$. Chempublish Journal, 2(1), 32-37.

Pramono, A., Rosariastuti, R., Ngadiman, \& Irfan, D. P. (2013). Bacterial Cr(VI) Reduction and Its Impact in Bioremediation. IImu Lingkungan, 11(2), 120-131.

Priadie, B. (2012). Teknik Bioremidiasi Sebagai Alternatif dalam Upaya Pengendalian Pencemaran Air. Jurnal Ilmu Lingkungan, 10(1), 38-48.

Qin, X. Y., Chai, M. R., Ju, D. Y., \& Hamamoto, O. (2018). Investigation of plating wastewater treatment technology for chromium, nickel and copper. IOP Conference Series: Earth and Environmental Science, 191(1), 012006. https://doi.org/10.1088/17551315/191/1/012006

Ribeiro, V. R., Fernandes, I. de A. A., Mari, I. P., Stafussa, A. P., Rossetto, R., Maciel, G. M., \& Haminiuk, C. W. I. (2019). Bringing together Saccharomyces cerevisiae and bioactive compounds from plants: A new 
function for a well-known biosorbent. Journal of Functional Foods, 60, 103433. https://doi.org/10.1016/j.jff.2019.103433

Sadyrbaeva, T. Z. (2016). Removal of chromium(VI) from aqueous solutions using a novel hybrid liquid membraneelectrodialysis process. Chemical Engineering and Processing: Process Intensification, 99, 183-191. https://doi.org/10.1016/j.cep.2015.07.011

Sharaf, S. A. A., Gasmeleed, G. A., \& Musa, A. E. (2013). Reduction of Hexavalent Chromium from Chrome Shavings. International Journal of Advance Industrial Engineering, 1(1), 24-27.

Tamam, M. H. B. (2016). Faktor yang Mempengaruhi Pertumbuhan Mikroorganisme.

Verma, S., \& Kuila, A. (2019). Bioremediation of heavy metals by microbial process.
Environmental Technology \& Innovation, 14, 100369. https://doi.org/10.1016/j.eti.2019.100369 Waluyo, L. (2019). Mikrobiologi Umum. Malang: UMM Press.

Wazeck, J. (2013). Heavy metal extraction from electroplating sludge using Bacillus subtilis and Saccharomyces cerevisiae (Schwermetallgewinnung aus Galvanikschlämmen durch Bacillus subtilis und Saccharomyces cerevisiae). Geologica Saxonica: Journal of Central European Geology, 59, 251-258.

Wolińska, A., Stępniewska, Z., \& Włosek, R. (2013). The influence of old leather tannery district on chromium contamination of soils, water, and plants. Natural Science, 5(2), 253-258. https://doi.org/10.4236/ns.2013.52A037 